\title{
Research and application of heat exchange system in Sun village coal mine
}

\author{
Li Xinghua, Xiao Bin, Zhang Limei \\ Shandong university of science and technology institute of mining and safety engineering
}

\begin{abstract}
With the rapid growth of economy in our country, the demand of coal will continue to increase. For a long time, the coal industry has continued with the extensive development and management model, but the study of its resources recycling is lack of necessary attention. By drawing from coal energy circulation development model at home and abroad, we have investigated sun village coal mine area seriously, study and analyze on the energy utilization, discuss the problem of the heat exchange system, then calculate the mining area heat load and the heat energy which can be extracted. By means of heat exchange system and reasonable allocation, the large amount of waste heat resources can be made full use in the mining area, meeting the demand of heating in the mine, reduce unnecessary waste and pollution, the hazard of mine safety, then save resources and bring the profit for the enterprise.
\end{abstract}

Keywords: coal industry, circular development mode, heat exchange

Although the total coal reserves are rich in our country, the recoverable reserves are limited.With the rapid development of economy, the demand for resources is growing day by day, the coal resources as the main energy position will not change in a short time. If we follow the traditional development model, unrestrained exploitation and utilization of these fossil fuels to consume a lot of resources in order to achieve industrialization and modernization of our country, our country will soon face the situation of energy depletion. Facing with the double pressure of energy demand growth and environmental protection, how to ensure energy supply and energy security, how to get rid of the traditional development model, based on the concept of circular economy and mode to promote the coordinated development of coal industry and the economy and the environment, speed up the transformation of mining area of heat exchange system, using a variety of techniques to extract the waste heat in the mine and recycling, is the key of the energy in our country to realizing the sustainable development.

\section{Basic principles of circular economy}

Circular economy is the material circulation, on the basis of the regeneration and utilization of economic development. Circular economy is the efficient utilization of resources and recycling for the purpose, with "reduction, reuse, recycling" as the principle, to realize low consumption, low emissions, high efficiency as the basic characteristics, and the reform of traditional operation mode.

For the current situation of China's economic development and energy use, the development of circular economy mode of "resources - products - Waste - renewable resources - recycled products" is the basic requirement of building a resource-saving and environment-friendly society, excessive waste recycling economy can solve resource. The development of circular economy is the inevitable choice of sustainable development of enterprises.

\section{Situation of Sun village coal energy utilization}

Sun village coal mine built in 1948, by relying on scientific and technological progress, it promotes technical innovation, constantly 
improves the production capacity, an annual output is 1.7 million tons of coal, well depth is 1300 meters, it has become one of the most mine deep mining. Due to the perennial constantly mining, underground coal mining area is thinner, recoverable coal is less and less, for better development, sun village rebuilds shaft in the north of the mining area. Sun village receives the former Hua Yuan source of coal mine coal power plant, the power plant from the mining area is 2 $\mathrm{km}$, and $5 \mathrm{~km}$ away from the vertical shaft mining area, the power plant provides hot standby ( $4 \mathrm{t}$ boiler spare), layout the wellhead in the mining area, as well as the main field building heating, working clothes drying and water bath heating, etc .But the process of energy waste is serious, in the process of mine construction and production, the mine constantly discharges a large amount of high temperature to ensure the normal operation of the mine groundwater, not only pollutes the environment, but also apper waste of resources; Within the mining area, air compressor in the running process produces a lot of heat, ensure the normal operation of air compressor for cooling the mine directly to the heat off, form the waste heat energy; mine will contain a large amount of heat and gas in coal mine air directly diacharged into the atmosphere, which caused great pressure to the environment at the same time, the greenhouse effect gets worse.

According to current situation of Sun village coal energy utilization, the heat exchange system reform is imperative, not only conducive to economic growth mode transformation of enterprises, promote the rational development and effective use of energy, but also to meet the heating needs of the mining area, reducing not unnecessary waste and pollution, reduce the risk of source in order to protect mine safety.

\section{Heat exchange system improvement of Sun village coal mine}

By investigating the sun village coal mine area, analyzing the sun village coal mine energy utilization, and having modification of the heat exchange system, the mining area makes full use of thermal energy, improves energy comprehensive utilization, reduces costs for coal mine and improve economic efficiency of coal enterprises.

\subsection{Heat preservation system of wellhead vertical shaft mining area}

Through the investigation of sun village coal mine shaft well existing research situation of heat preservation, shaft mining area provided by power plant heat steam into hot water to heat preservation of wellhead, is about $5 \mathrm{~km}$, there exists the problems such as the long distance for the wellhead insulation system transfer, high cost, the large amount of thermal energy whether it can be effectively used, aiming at the problems, we use wind heat hot water system and air compressor machine technology to adjust the existing mine well thermal insulation system and optimization, to achieve thermal optimization using and realize wellhead anti-freeze and heat preservation.

According to the survey, mine ventilation air temperature is high, producing a lot of heat air compressor operation, but the coal mine does not have effective utilization, resulting in waste of resources. Wellhead thermal load and vertical shaft mining area can provide heat such as table 1. So it can use original ventilation air heat exchange system, making the system of circulating water heat to $24{ }^{\circ} \mathrm{C}$ or so. It uses the circulating water and the treated mine drainage directly into the shaft well, through the energy company development and production of special wellhead heaters, realize wellhead heating and antifreeze; Re-use of energy water heater, air compressor developed to extract waste heat from the process of the preparation of the mine shaft compressor running hot water produced, fed into the existing wellhead heating system to ensure that airflow into the shaft wellhead winter temperature $\geqslant 2{ }^{\circ} \mathrm{C}$. The improved wellhead insulation system schematic diagram is as 
follows:

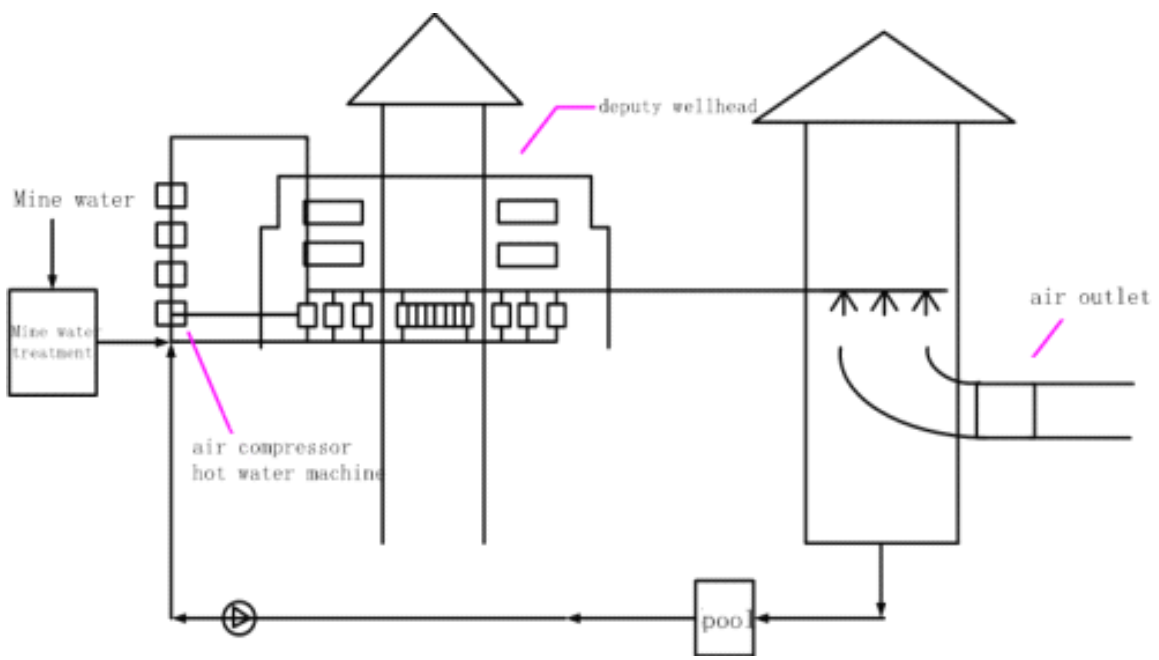

Figure 3.1 Vertical shaft mining well thermal insulation and antifreeze system

Table 1 Vertical shaft wellhead heat preservation heat load and heat energy

\begin{tabular}{ccc}
\hline Classification & Heat load & heat source provided \\
\hline Vertical shaft well thermal insulation & $3562 \mathrm{kw}$ & \\
Building heating & $91 \mathrm{kw}$ & $4585 \mathrm{kw}$ \\
Return air heat transfer & & $1163 \mathrm{kw}$ \\
Mine drainage & $6200 \mathrm{kw}$ \\
\hline Total & $3653 \mathrm{kw}$ & 62 \\
\hline
\end{tabular}

\subsection{Comprehensive utilization of heat energy system in a main field living area and office area}

Through the investigation on the main area of the living area, energy utilization is mainly reflected in the winter heating, the hot water and bath water supply, having a good living environment can ensure coal mine employees focus on their work; office area of thermal energy utilization is mainly manifested in working clothes drying, winter heating and hot water supply throughout the year in the industry, there is a good working environment, mining leaders to develop more effective strategies to create conditions for enterprises to rapidly increase profits. But sun village coal mine in the living area and office area use the power plant steam heating, which cause a heat transmission distance, and a serious energy waste phenomenon.

According to the mining area of on-the-spot investigation, $2 \mathrm{~km}$ from the area of power plant, will produce a large number of condensed water when it provides hot steam externally, this part of the condensate temperature is relatively high, and can take its extract heat temperature difference to satisfy the life of the mining area and office. Available heat load and heat are 
shown in table 2. The condensate return charge thermal technology makes comprehensive use of the mining area of thermal energy, achieve energy conservation, emissions reduction, and reasonable optimization. Improved the main field of comprehensive utilization of heat energy system schematic diagram is as follows:

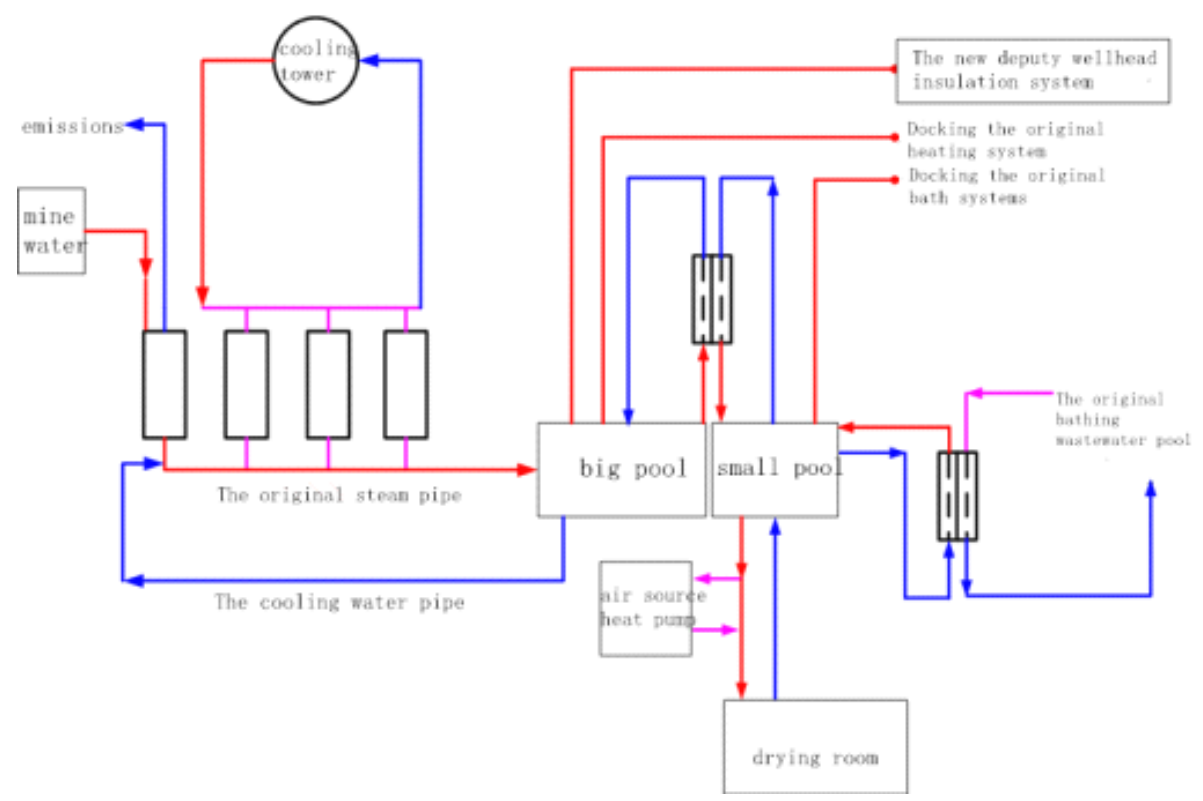

Figure 3.2 Main field heat energy comprehensive utilization system

Table 2 Main field living district heat load and heat energy

\begin{tabular}{ccc}
\hline Classification & Heat load & heat source provided \\
\hline Building heating & $22264 \mathrm{kw}$ & \\
Bath water & $1453 \mathrm{kw}$ & \\
Working clothes to dry & $36 \mathrm{kw}$ & $27907 \mathrm{kw}$ \\
Well insulated & $759 \mathrm{kw}$ & $27907 \mathrm{kw}$ \\
Condensed water recycling & & $24512 \mathrm{kw}$ \\
\hline Total
\end{tabular}

\subsection{Comprehensive utilization of other energy sources}

It saves power plant steam transportation cost and time, and avoids the heat loss in the transport way through the vertical shaft well thermal insulation system and improvement of the comprehensive utilization of main field system. For power plant, the heat steam saved for mining area transportation is a very good opportunity, can be combined with the thermal power plant to gain extra profit of building heating, not only did not result in the loss of business cooperation to decline their performance, but will greatly promote the 
development of enterprises.

By the survey of sun village site, it is found that the coal mining area of power plant produces boiler flue gas emissions in the process of production, containing a great deal of heat, which is heat energy waste. According to this heat source, the energy company tails smoke wastes heat boiler heat recovery technology, heat source, mining and reasonable planning and utilization, to improves the efficiency of the power plant.

\section{Systematical efficiency improvement analysis}

Benefit analysis plays a very important role when making the development strategy of a enterprise. To improve the heat exchange system of the coal is not only need to feasible in theory, but also need to satisfy the coal enterprise. We need to collecting the heat energy data, summarize the factors affecting the heat exchange efficiency of sun village coal mine, the shaft well thermal insulation system, the main field heat energy comprehensive utilization system and Other energy comprehensive utilization benefit analysis. Coal enterprises guidance can better saving and emission reduction, use of energy, the development of cyclic economy to improve the efficiency of enterprises. Before and after modification heating system operation cost shown in the following table:

Table 3 The original heating system operation cost

\begin{tabular}{|c|c|c|c|c|}
\hline \multirow[b]{2}{*}{ Project } & \multicolumn{2}{|c|}{ Main shaft } & \multicolumn{2}{|c|}{ Vertical shaft } \\
\hline & $\begin{array}{l}\text { Building } \\
\text { heating }\end{array}$ & $\begin{array}{c}\text { Deputy wellhead } \\
\text { insulation, washing } \\
\text { and drying }\end{array}$ & $\begin{array}{l}\text { Building } \\
\text { heating }\end{array}$ & $\begin{array}{c}\text { Deputy wellhead } \\
\text { insulation }\end{array}$ \\
\hline The steam consumption & 63535.0 & 26887.0 & & 5263.8 \\
\hline Steam the unit price & 160.0 & 160.0 & 160.0 & 160.0 \\
\hline Fee (ten thousand yuan) & 1016.6 & 430.2 & & 84.2 \\
\hline $\begin{array}{l}\text { Operation of electricity } \\
\text { (ten thousand yuan) }\end{array}$ & \multicolumn{2}{|r|}{31.5} & \multicolumn{2}{|r|}{16.6} \\
\hline $\begin{array}{l}\text { Artificial cost (ten } \\
\text { thousand yuan) }\end{array}$ & \multicolumn{2}{|r|}{60.0} & \multicolumn{2}{|r|}{14.4} \\
\hline $\begin{array}{l}\text { System maintenance fee } \\
\text { (ten thousand yuan) }\end{array}$ & \multicolumn{2}{|r|}{25.0} & \multicolumn{2}{|r|}{1.5} \\
\hline subtotal & \multicolumn{2}{|c|}{1563.3} & \multicolumn{2}{|c|}{116.7} \\
\hline total & \multicolumn{4}{|c|}{1680.0} \\
\hline
\end{tabular}

Table 4 After transforming heating system operation cost

\begin{tabular}{|c|c|c|c|}
\hline \multirow{2}{*}{ Project } & \multicolumn{2}{|c|}{ Main shaft } & Vertical shaft \\
\cline { 2 - 4 } & Winter heating & $\begin{array}{c}\text { washing and } \\
\text { drying }\end{array}$ & Heating and well insulated \\
\hline $\begin{array}{c}\text { Operating cost (ten thousand } \\
\text { yuan) }\end{array}$ & 495 & 113 & 20 \\
\hline
\end{tabular}




\begin{tabular}{|c|c|c|}
\hline $\begin{array}{c}\text { Cost of the original system } \\
\text { (ten thousand yuan) }\end{array}$ & 1563.3 & 116.7 \\
\hline $\begin{array}{c}\text { Annual cost savings (ten } \\
\text { thousand yuan) }\end{array}$ & 955.3 & 96.7 \\
\hline Saving rate & $61 \%$ & $83 \%$ \\
\hline
\end{tabular}

By improving the three subsystems to complete the overall Sun village coal mine planning, implementation issues that may arise during the forecast, timely construction of improvements to the system when problems arise, to further improve the system reliability. To Guide coal enterprises better conservation and emission reduction, use of energy to develop the circular economy, therefore improve the efficiency of enterprises.

\section{Conclusions}

The coal, acting as the most reliable and guaranteed energy in the development of economic, can not be replaced by other energy, its dominant position in the economic development of energy consumption will not change easily in our country. Along with the rapid growth of economy in our country, the demand for coal will be continued to increase. The development of recycling economy of coal industry should be based on saving the energy in the process of production and consumption, and deducting the amount of waste energy, reusing the waste recycling, and "waste zero emission", and continuously improving the heat exchange system in the mining area, making full use of resources, promoting synchronous growth of the economic benefits, social benefits and environmental benefits.

This paper summarize the situation of Sun village coal, the status of the mine can be analyzed by using statistical data, put forward by using the theory of circular economy in the mining area of heat, through reforming of the wellhead insulation system, the main living area and office area mining heat utilization systems and other energy system transformation, optimized heat exchange system in the mines.
Therefore, saving energy consumption, protecting environment, improve enterprise efficiency. Meanwhile circular economy is a new economic development model, it still need to explore much more research because this is only part of the study, other factors also need to be perfect analysis in the future.

\section{Reference}

[1].Fu Yueqin. The circulation economy development model of coal industry and its application study $[\mathrm{J}]$. China University of geosciences (Beijing). 2013.4

[2]Zhang Yan. The situation of coal circulation economy development in our country. [J].2010.2 [3] Li Baoyu. Research of coal enterprise circular economy development strategy and its model [J]. Journal of coal economic research, 2011, 31 (2): 17-21.

[4] Xia Qing, Li Zhongxue, Liang Yu. Facing the mining development of circular economy [A]. Geology and mineral resources of China economy, 2003, (2): $14-15$ 